\title{
The Development of a Physical Education Teaching Model in the Covid - 19 Situation Based on the Concept of Active Learning with Digital Technology Media of Students in the Field of Physical Education and Health, Faculty of Education Thailand National Sports University Chon Buri Campus
}

\author{
Jirawat Khajornsilp $^{1, *}$, Sobson Mahaniyom ${ }^{1}$ \& Aungsumalin Kenjaturas ${ }^{1}$ \\ ${ }^{1}$ Faculty of Education, Thailand National Sports University, Chon Buri Campus, Thailand \\ *Correspondence: Thailand National Sports University, 111 Sukhumvit, Nongmaidaeng, Meung, Chon Buri 20000, \\ Thailand. Tel: 66-80-967-5600.E-mail: jirawatkh@kurupatana.ac.th
}

Received: August 13, 2021

Accepted: September 13, $2021 \quad$ Online Published: November 15, 2021

doi:10.5430/jct.v10n4p55

URL: https://doi.org/10.5430/jct.v10n4p55

\begin{abstract}
The objectives of this research were: 1. to develop a teaching model of physical education after the COVID-19 situation based on the concept of proactive learning in combination with digital technology media; 2 . to compare the students' proactive learning behavior with digital technology media between the experimental group and the control group 3. Assess the students' higher thinking between the experimental group and the control group 4. Assess the satisfaction of students who manage learning by using a proactive learning management model and digital technology media. Affecting the effect of using the model the sample group used in the interview research there were 5 professors of the Faculty of Education and 15 students. The sample group that used the model to teach students was 30 students, divided into an experimental group of 15 , and students trained by students of 300 people, a control group of 15 and students who were trained. 300 teaching students by random sampling. Tools include Document analysis record form interview questions Questionnaire on learning management conditions Program to develop faculty members to measure readiness in learning management Learning Behavior Assessment and Learning Satisfaction Questionnaire Qualitative data were analyzed by content analysis. Quantitative data analysis using basic statistics such as percentage, mean, standard deviation variance the differences between the mean were compared using the covariance analysis (ANCOVA) t-test statistic and the efficiency was analyzed. Process/efficiency of results.

The results showed that 1 . Physical education teaching style in the situation of COVID-19 Based on the concept of proactive learning with digital technology media there are 6 steps in learning management (PODARE).

2. Comparison of proactive learning behavior with digital technology media the experimental group was significantly higher than the control group at the .01 level. 3. The results of the assessment of advanced thinking of the experimental group of students who received learning management according to the proactive learning management model with digital technology media. Have a good high thinking score. Accounted for $43.83 \%$

4. The results of the satisfaction assessment of the students who participated in the development of the model were of the opinion that the model made the students more clear and clear about proactive learning management with digital technology media. When students change the way they organize learning and activities in the classroom change, students change their learning behavior. Make students have more participation behavior in class.
\end{abstract}

Keywords: physical education teaching model, students in the field of physical education, active learning

\section{Introduction}

Curriculum in higher education management in Thailand is currently unable to keep up with the current events and changes in the world. In 2014, the government established the National Reform Council. It has set the agenda for reform of the higher education system, science, research and innovation. This is considered to be one of the key 
reform agendas for higher education management to adjust the paradigm, development direction and operations in higher education, science, research and innovation (seine) to be consistent and integrated to create a force and power to drive the development of the country. The Government Gazette, Volume 136, Part 57 announced on May 1, 2019 Establishment of the Ministry of Higher Education, Science, Research and Innovation (The Reform Act of Ministries, Departments (No. 19), B.E. 2562) and from such reforms Causing a great awakening to the management of higher education. Ma-un (2016) has mentioned about the management of education at the higher education level that effective teaching and learning management in higher education consist three issues. The first point is the nature of teaching and learning at the higher education level. The second point is the higher education curriculum. The third point is the effective teaching and learning management at the higher education level. The details of the 3rd issue are as follows: 1) educational cycle and teaching in higher education, 2) teaching design and teaching planning, 3) teaching evaluation, and 4) teaching styles and teaching methods for higher education. Chularat (2018) has mentioned about the modern curriculum in the present era. Courses must respond to the global labor market and are up-to-date with the events in the digital era. The courses should be able to develop society and the nation in the age of Thailand 4.0, which drives the country with technology, creativity and innovation towards "wealth, stability and sustainability." Thailand has to create its own innovations. Therefore, education must accelerate learning reform for learners to step into "Education 4.0" in a concrete way as well Education in Thailand 4.0 is not just about educating people or learners but to prepare human beings. This is consistent with Ying (2020) In an internationalized curriculum in specific discipline, it is important to incorporate the development of intercultural competence into the teaching and learning activities in a more detailed and well-organized way for delivering global-ready graduates. An effective pedagogical environment is needed to guide students to understand the commonality and difference between cultures. And it is equally necessary to make sure that the assessment criteria align with the intended learning outcomes and learning activities. Multimethod or multiperspective assessment is suggested to provide a comprehensive picture for its development and facilitation in internationalizing the curriculum.

In this era of information and economic globalization, developing critical thinking skills in college students has been set as a primary goal and learning outcome in higher education. Teaching critical thinking. (Feng, 2013). Future teachers who take more teaching courses prefer a democratic atmosphere and are intrinsically more motivated. When explaining future teachers' attitudes towards a democratic teaching process. (Koludrović \& Ercegovac, 2017). Education Management of the Ministry of Education has established the National Education Act B.E. 2542 and its amendments (No. 2) B.E. 2545 and (No. 3) B.E. stated that the management of education must be in order to develop Thai people to be complete human beings, both physically, mentally, intellectually, knowledge and morality, having ethics and culture to live happily with others and has set guidelines for educational management in section 4, section 22 states that education management must be based on the principle that all learners have the ability to learn and develop themselves and are considered the most important. Educational management process should encourage learners to be able to develop naturally and full potential and Article 24 states that the learning process, educational institutions and related agencies to organize content and activities in accordance with their interests. And aptitude of learners taking into account differences between individuals Allow students to practice skills, thinking processes, and coping with situations. And applying knowledge to prevent and solve problems, organize activities for learners to learn from real experiences Practice to be able to think and act as a love of reading and continual curiosity. Alyami (2020) showed that Open educational resources (OER) have become a strategic source of a high degree of importance Motivating and training educators and students, supporting, and disseminating the culture of free access and OER. Exploration of cooperation among the universities and educational institutions and making strategic plans to adjust OER for the shared needs of the higher and general education. Creating and publishing manuals of the channels and platforms of OER via the website of the Ministry of Education for the members of the educational community.

Teaching at the higher education level, especially in the field of physical education may be taught in a large field with a large number of students. For this reason, it is difficult to manage event interaction with learners Classroom measurements and assessments especially after the COVID-19 situation. Therefore, it requires teachers who are highly experienced and have teaching techniques that can immobilize students. However, there are different types of learning process arrangements according to the course characteristics and readiness in technology including the physical characteristics of the school This is consistent with Sukdee \& Chankuna (2021) showed that adjustment in physical education and sports learning after the COVID-19 pandemic is of great importance. Students are required to always follow COVID-19 preventive measures in Physical Education and Sports classes to gain the most knowledge. Establishing a relationship with one's surroundings through supplies of facilities and interactions with fellow humans through imitation, keeping up with changes in the world through logical intelligence development by holding 
knowledge expanding activities, and class management as the university's policy will help in understanding such situations. Ghazala, \& Elshall (2021) the emergence of COVID 19 disaster, dependence on technological and electronic learning is increasing. National Education technology standard has a great impact on improving students' skills. It is very important to ensure application of national education technology standards for teaching staff and administrative system.

For the 21st century, the learning process is trying to change the role of the teacher from a speaker to an instructor and jointly design activities in organizing the learning process so that learners can build their own body of knowledge. And share the knowledge gained with friends in the classroom. This is an active learning that takes the student center is an innovation in learning management that corresponds to the development of learners' skills in the 21 st century, which has changed from an instructor lecturing content in the classroom to creating or introducing learning materials for learners to return to study at home. Then, the teacher should turn the activities in the classroom into activities from the lessons learned by the students to practice skills problem solving practice. Moreover it is also important to create interactions within the classroom including applying knowledge. Therefore, proactive learning is considered a type of teaching and learning that encourages learners to conform to the changes in the present era. In addition, teaching and learning management techniques that focus on creativity are also required. Romualdas \& Tomas (2020) 21 st century physical education teachers more often showed solidarity, raised other's status, gave help, reward, more often encouraged others, were calmer, more satisfied and communicated. Ghafar (2020) showed that the development of convergent 21 st century skills such as social relationships, leadership, creativity and critical thinking further nurture entrepreneurial intents among students.

Due to the COVID-19 epidemic situation, people are concerned all over the world. The country has been shut down to prevent the spread of the disease lonely airport Tourist attractions are almost deserted teaching and learning in general schools are problematic. Therefore, teachers need to adjust their teaching methods in accordance with the changes in the technological society and the current situation and learning of learners from the teacher is the broadcaster. This changes the role of a guide on how to search for knowledge to develop learners to be able to seek knowledge and apply skills create self-understanding until it becomes a meaningful learning by providing proactive learning together with the use of digital media that focuses on transferring knowledge from teachers to learners directly based on the learning management process in which the learner has taken action and has used the thinking process about what has been done, the teaching methods and various teaching techniques are used to design learning management plans and activities. The teacher should also encourage students to participate in class and encourage interaction between learners and learners and learners with teachers. Therefore, proactive learning is considered a type of teaching and learning management that encourages learners to have characteristics consistent with the changes in the present era. In addition, it also requires teaching and learning management techniques that focus on the creation of knowledge by the learners themselves according to their skills, knowledge the ability and intelligence of the individual competency through various information technology media independently outside the classroom, such as through social networks and the e-learning system. These are different from the traditional learning where the instructor will be the one who feeds knowledge and experience to the learners by practicing applying knowledge in various situations. To achieve "MASTERY LEARNING", which is a way to use the classroom to create value for learners will truly change the role of the teacher as the teaching director Panich. (2013). It is not just a knowledge transfer person but will inspire self-study from learning materials based on learning objectives. Attending class is to think critically, synthesize and create innovation. Learners and educators work together to create a valuable learning method. Thus, to build advanced thinking skills, the proactive learning management model together with the use of digital media is an innovation in learning management that is in line with the development of learners' skills in the 21 st century and the situation of the covid-19 epidemic that has changed from teachers to lecture content in the classroom. It is the creation or introduction of learning materials for students to return to study at home and turn classroom activities into activities from the lessons learned by the students to practice skills practice solving problems, creating interactions in the classroom including the use of knowledge to make teaching in large classrooms more effective. This will allow future students to have a way of thinking about working know how to use information technology have knowledge of information and have skills for living in today's world.

From the reasons and necessities mentioned above, both from the reform of higher education management, changing according to the modern world and from the situation of the spread of COVID-19 that hinders teaching management, the researchers are interested in the development of teaching model after the Covid-19 situation of students in Physical Education and Health Education Based on the concept of active learning with digital technology media for students to use the teaching method as a model in teaching and learning when students go out to practice teaching or after graduating to become a physical education teacher in various schools. 


\section{Method}

\subsection{Objectives}

1) To develop a teaching model for physical education after the Covid-19 situation according to the concept of active learning in conjunction with digital technology media of students in the field of physical education and health education Faculty of Education Thailand National Sports University Chon Buri Campus.

2) To compare the student's achievement Physical Education and Health Education Faculty of Education Thailand National Sports University Chon Buri Campus during the traditional physical education teaching management with the management of physical education teaching in the Covid-19 situation Based on the concept of active learning with digital technology media.

3) To study the factors affecting student achievement Physical Education and Health Education Faculty of Education Thailand National Sports University Chon Buri Campus that uses the teaching model of physical education in the Covid-19 situation according to the concept of active learning with digital technology media.

4) To study the satisfaction towards the model of physical education teaching management in the Covid-19 situation according to the concept of active learning with digital technology media of students in Physical Education and Health Education Faculty of Education Thailand National Sports University Chon Buri Campus.

\subsection{Conceptual Framework}

The principles, concepts and theories of active learning together with digital technology media were applied to develop the teaching model of physical education in the Covid-19 situation of students in Physical Education and Health Education based on the concept of active learning with technology media digital technology media. The developed model was verified the quality and used to teach students Physical Education and Health Education Faculty of Education Thailand National Sports University Chon Buri Campus to determine the quality of physical education teaching model in the Covid-19 situation according to the concept of active learning in conjunction with technology media digital technology media by comparing the learning achievement and satisfaction with opinions on the model of physical education learning management in the Covid-19 situation according to the concept of active learning with digital technology media.

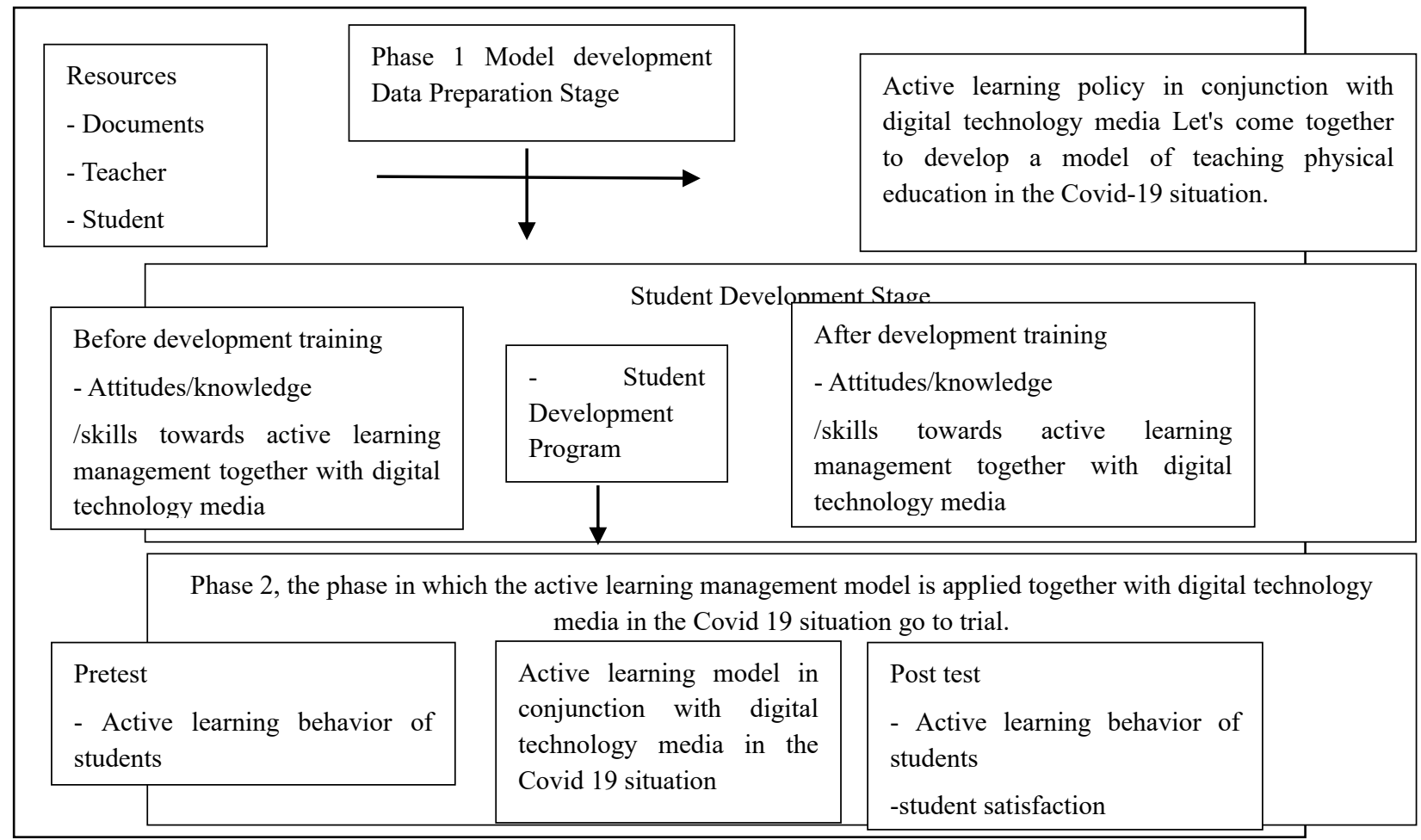

Figure 1. Conceptual Framework 


\subsection{Ethical Considerations}

The researchers clearly explained the purpose and the procedures of the study to the participants and then obtained their informed consent. This study was approved by the Human Research Ethics Committee, Thailand National Sports University (certification number: TNSU 019/2564).

Every individual in the sample group was informed of terms and conditions and agreed to participate as the sample group of this research. The researchers personally explained the details of the research and provided a consent form for participators to sign. Consent was asked of volunteers or their rightful representatives. Aliases were used instead of real names. Moreover, names of those involved or caused impact on the sample group were not revealed. The research results were presented as conclusions, which were of no influence to those in the sample group.

\section{Phase 1}

\subsection{Research Process}

Developing an active learning management model with digital technology media.

1) Study concepts, documents, textbooks, and researches related. Invite five experts to verify the quality of the semi-structured in-depth interview to determine its validity by finding the index of item - objective congruency (IOC). The IOC value was between 0.60 and 0.80 . Then, the researchers selected group 1 to interview, examine and help assess research and development of physical education teaching model in the COVID-19 situation. According to the concept of active learning with digital technology media of students in Physical Education and Health Education Faculty of Education Thailand National Sports University Chon Buri Campus Qualifications to be professors of the Faculty of Education, consisting of 5 people

1.1) Chairperson of the Physical Education Program 1 person

1.2) Educational technology instructors, 2 people

1.3) Instructors in charge of the physical education program, 2 people

2) Five experts were invited to verify the quality of the semi-structured in-depth interview to determine its validity by finding the index of item - objective congruency (IOC). The IOC value was between 0.60 and 0.80 . Then, the researchers selected Group 2 the group used to verify the suitability of the model. They were qualified to be physical education and health education students Faculty of Education Thailand National Sports University Chon Buri Campus. There were 15 people who registered for vocational training courses during the first semester of the academic year 2021.

\subsection{Results}

The results of the development of physical education teaching model in the Covid-19 situation according to the concept of active learning with digital technology media of students in Physical Education and Health Education Faculty of Education Thailand National Sports University Chon Buri Campus can be summarized as follows:

1) In terms of graduate Production Policy in Physical Education and Health Education Faculty of Education Thailand National Sports University Chon Buri Campus, the notion for the faculty to manage learning to develop students to have desirable characteristics according to the Faculty's identity is to be good people and professional practitioners. Therefore, what must be cultivated in the student's identity is Academic skills according to the course of the field of study 21 st century skills to stand firm keep up with the world in terms of learning Information, technology, and work and living skills, morality, ethics, diligence have the ability to communicate able to adapt work with others.

2) The condition of learning management of students when they became teachers. It was found that the learning management methods of students. Most of them still focused on teaching with an emphasis on academic knowledge in the classroom using lecture-based teaching because the students believed that students still lack the skills to seek knowledge on their own.

3) The condition of the learning process of the students that the students went to teach teaching found that they had more lecture-based learning behaviors than classroom participation and lacking desirable attributes such as punctuality regularity in attendance Lack of self-study skills Lack of advanced thinking skills, etc.

4) The need for learning management of students found that the students needed to develop themselves in teaching and teaching techniques in addition to lectures to students. They also needed to learn more on how to manage the learning that students want to learn more which is about Activity-Base Learning. However, some students are unsure of the 
current learning management they use. It is considered a proactive learning management because of a lack of understanding of the concepts and principles of learning active.

5) Results of the development of a model of active learning management by interviewing experts who participated in the development of physical education teaching model in the Covid-19 situation based on the concept of active learning with digital technology media of students in Physical Education and Health Education Faculty of Education Thailand National Sports University Chon Buri Campus found that the teaching style of physical education in the Covid-19 situation based on the concept of active learning with digital technology media of students in Physical Education and Health Education Faculty of Education Thailand National Sports University Chon Buri Campus consisted of the main principles of the model which were the purpose of the pattern, the process of learning management of the model and the results of the learning management according to the model which the model of learning management developed called "PODARE Model"

6) The results of verifying the suitability of the model before being used for the trial showed that the physical education teaching style in the COVID-19 situation based on the concept of active learning with digital technology media of students in Physical Education and Health Education Faculty of Education Thailand National Sports University Chon Buri Campus created to be appropriate and effective in accordance with the opinions of experts and students.

Physical education teaching style after the Covid-19 situation based on the concept of proactive learning with digital technology media, consisting of (1) Preparation: P (2) Orientation: O (3) Demonstrate: D (4) Action: A

(5) Reinforcing active learning behaviors with digital technology media: R and (6) Evaluation: E

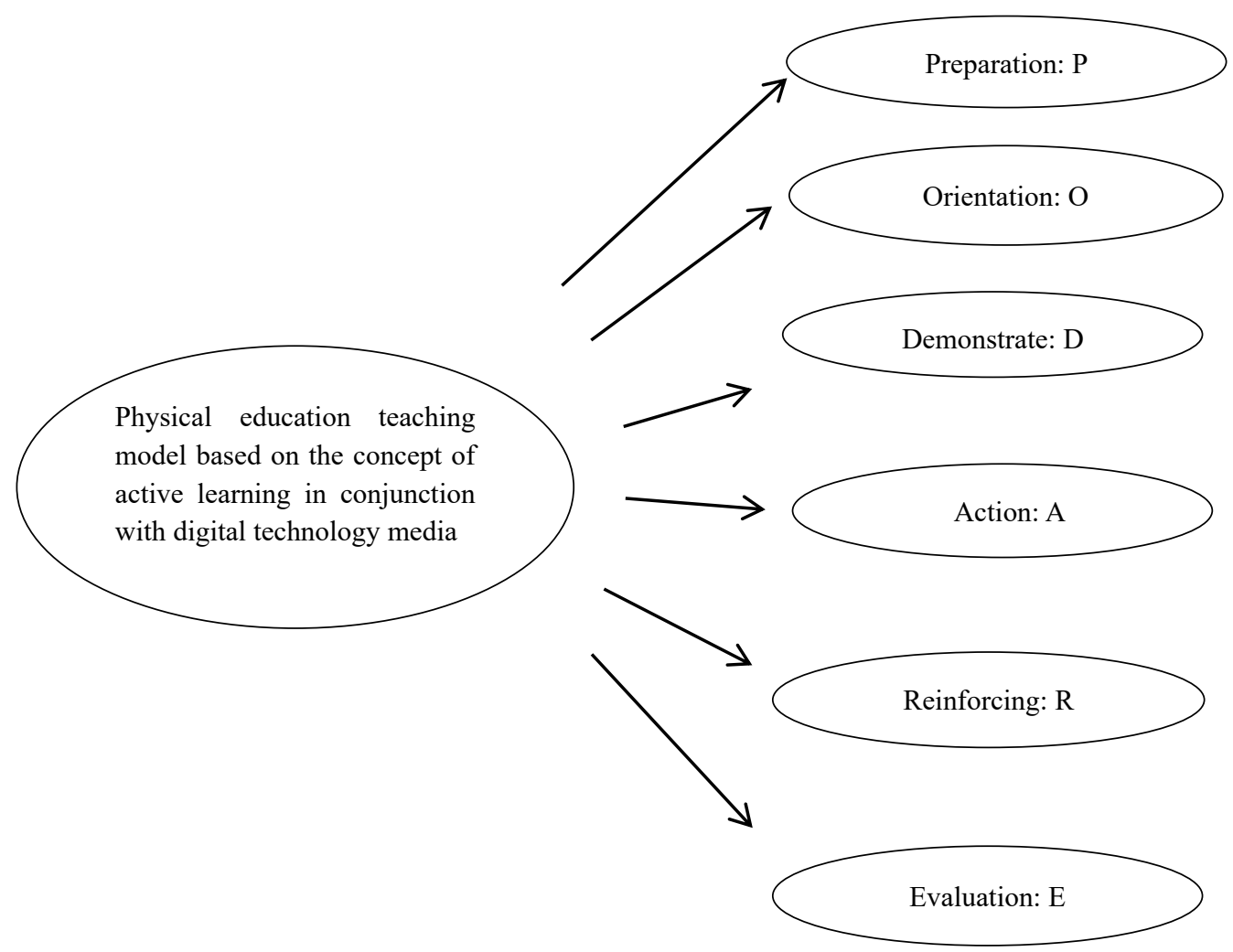

Figure 2. Physical Education Teaching Model Based on the Concept of Active Learning in Conjunction with Digital Technology Media

\section{Phase 2}

\subsection{Research Process}

Physical education teaching model after the Covid-19 situation were based on the concept of active learning with digital technology media of students in Physical Education and Health Education Faculty of Education Thailand 
National Sports University Chon Buri Campus. The teaching model was conducted teaching in real situations in the first semester of the academic year 2021. The sample group was comprised of 30 physical education and health education students Faculty of Education Thailand National Sports University Chon Buri Campus who registered for the course of vocational practice during class 1 . The experimental group consisted of 15 people who used the teaching model of physical education after the COVID-19 situation based on the concept of active learning with digital technology media and the control group consisted of 15 people who used traditional physical education teaching method.

1) Comparison of students' active learning behavior with digital technology media between the experimental group in which students managed their learning by using an active learning management model with digital technology media and the control group that students managed to learn using traditional physical education teaching method.

2) Assessment of advanced thinking of students in the experimental group that students managed to learn by using an active learning management model with digital technology media and the control group that students managed to learn using traditional physical education teaching method.

3) Assessment of student satisfaction with learning management by using a active learning management model with digital technology media on the effect of using the active learning management model with digital technology media that has been created.

\subsection{Results}

1) Comparison of active learning behavior with digital technology media of students in the experimental group that students managed to learn by using a model of active learning management with digital technology media.

Table 1. Shows the Average Scores of Active Learning Behavior with Digital Technology Media

\begin{tabular}{llll}
\hline Group & number of students & $\bar{X}$ & S.D. \\
\hline Experimental group & 300 & 6.180 & .564 \\
Control group & 300 & 3.685 & .632 \\
Sum & 600 & 3.932 & 1.383 \\
\hline
\end{tabular}

Table 2. Shows the Comparison of Students' Post-study Active Learning Behavior Scores between the Experimental Group and the Control Group

\begin{tabular}{llllll}
\hline Source of Variance & Sum of Square & df & MS & F & Sig \\
\hline Active learning behavior & 64.252 & 1 & 64.252 & 169.196 & .285 \\
Teaching style & 1194.230 & 1 & 1194.230 & 3152.376 & $.000^{* *}$ \\
Discrepancy & 277.122 & 700 & .397 & & \\
\hline
\end{tabular}

$* * \mathrm{p}<.01$

The active learning behaviors in combination with digital technology of students in the experimental group and the control group were different. It was statistically significant at the .01 level by active learning behavior with digital technology media of students in an experimental group that students manage to learn by using a active learning management model with digital technology media The average was higher than the control group that the students managed to learn using the normal model.

2) Assessment of advanced thinking of students in an experimental group that students manage to learn by using a active learning management model with digital technology media and a control group in which 600 students managed to learn using a normal model. 
Table 3. Shows the Assessment of Advanced Thinking of the Students in the Experimental Group

\begin{tabular}{|c|c|c|c|}
\hline Average & Meaning & Number (person) & Percentage \\
\hline $3.01-4.00$ & $\begin{array}{l}\text { Very good, the work demonstrates the ability to } \\
\text { collect cognitive data application of } \\
\text { Analyze, synthesize and innovate. }\end{array}$ & 120 & 20.000 \\
\hline $2.01-3.00$ & $\begin{array}{l}\text { Good, the work demonstrates the ability to collect. } \\
\text { cognitive information and the application } \\
\text { Analyze, solve problems or develop in depth work. }\end{array}$ & 263 & 43.833 \\
\hline $1.01-2.00$ & $\begin{array}{l}\text { Fair, the work demonstrates the ability to lead. } \\
\text { Knowledge and understanding can be applied well in } \\
\text { various situations. }\end{array}$ & 97 & 16.167 \\
\hline $0.51-1.00$ & $\begin{array}{l}\text { The work demonstrates an understanding of the } \\
\text { knowledge learned. }\end{array}$ & 76 & 12.667 \\
\hline \multirow[t]{2}{*}{$0.00-0.50$} & $\begin{array}{l}\text { The work does not represent an understanding of the } \\
\text { knowledge learned. }\end{array}$ & 44 & 7.333 \\
\hline & Summarize & 600 & 100 \\
\hline
\end{tabular}

The experimental group of students received learning management according to the proactive learning management model with digital technology. The score of advanced thinking was at a good level, representing $43.83 \%$, followed by a score of advanced thinking at the level very good, representing 20 percent and having a good advanced thinking score accounted for 16.17 percent, respectively.

3) Assessment of student satisfaction with learning management by using a active learning management model with digital technology media on the effect of using the active learning management model with digital technology media that has been created.

Table 4 Student satisfaction towards learning management by using a active learning management model with digital technology media

From Table 4, it was discovered that the students who received the learning management according to the model with the developed digital technology media had a good overall satisfaction with the active learning $(\overline{\mathrm{x}}=3.948)$. The learning activities of teachers are diverse, not focusing on lectures alone the most $(\overline{\mathrm{x}}=4.41)$, followed by the teachers informing the objectives and agreements of the teaching style to be used before every study $(\bar{x}=4.40)$, teachers reviewing the knowledge they have learned each time $(\overline{\mathrm{x}}=4.35)$ teachers Using questions during learning activities gave students more practice in thinking and problem solving $(\overline{\mathrm{x}}=4.11)$, and learning activities made students more hands-on than listening to lectures alone $(\overline{\mathrm{x}}=4.08)$.

4) After participating in the development of a model of proactive learning management with digital technology media and applying the model to an experiment, 15 students in the experimental group were of the opinion that the model of proactive learning management with digital technology media made the students more Knowledge and understanding of proactive learning management with digital technology media more clear When students change their methods Manage learning activities in the changing classroom. Students also had a change in learning behavior. Make students have more participation behavior in class. 
Table 4. Student Satisfaction towards Learning Management by Using a Active Learning Management Model with Digital Technology Media

\begin{tabular}{|c|c|c|c|c|}
\hline \multirow[t]{2}{*}{ Article } & \multirow[t]{2}{*}{ Satisfaction assessment items } & \multicolumn{2}{|c|}{ Satisfaction level } & \multirow[b]{2}{*}{ level } \\
\hline & & $\overline{\mathbf{X}}$ & S.D. & \\
\hline 1. & $\begin{array}{l}\text { The teacher informs the purpose and agreement of the teaching style to } \\
\text { be used before every lesson. }\end{array}$ & 4.400 & .771 & good \\
\hline 2. & $\begin{array}{l}\text { Before class, the teacher distributes a mass of teaching experiences, } \\
\text { activities and measurements to students. }\end{array}$ & 3.900 & .852 & good \\
\hline 3. & $\begin{array}{l}\text { The teacher gives students the opportunity to comment on the activities } \\
\text { and the measurements reported. }\end{array}$ & 3.980 & .887 & good \\
\hline 4. & $\begin{array}{l}\text { The teacher reviews the knowledge they have learned from the past } \\
\text { every time. }\end{array}$ & 4.350 & .773 & good \\
\hline 5. & $\begin{array}{l}\text { Learning activities organized by students provide opportunities for } \\
\text { students to work in groups and to discuss and exchange ideas among }\end{array}$ & 3.900 & .748 & good \\
\hline 6. & themselves. & 4.080 & .766 & good \\
\hline 7. & $\begin{array}{l}\text { Learning activities allow students to do more than just listening to } \\
\text { lectures. }\end{array}$ & 4.110 & .881 & good \\
\hline 8. & $\begin{array}{l}\text { The teacher uses questions during learning activities to give students } \\
\text { more practice in thinking and problem solving. }\end{array}$ & 3.860 & .788 & good \\
\hline $\begin{array}{l}9 . \\
10 .\end{array}$ & $\begin{array}{l}\text { Learning activities give students more practice in presenting their own } \\
\text { and group work. }\end{array}$ & 4.410 & .772 & good \\
\hline & Teachers' learning activities are diverse, not focusing on lectures alone. & 3.850 & .870 & good \\
\hline 11. & $\begin{array}{l}\text { Organizing teaching activities to reinforce the participatory behaviors } \\
\text { expressed by the students. }\end{array}$ & 3.980 & .772 & good \\
\hline 12. & $\begin{array}{l}\text { At the end of the learning activities, the teacher gives feedback to the } \\
\text { students every time. }\end{array}$ & 4.010 & .820 & good \\
\hline 13. & $\begin{array}{l}\text { Every time the learning activities are held at the end of the period, } \\
\text { students summarize the results for the students. }\end{array}$ & 3.780 & .776 & good \\
\hline 14. & $\begin{array}{l}\text { Summarizing the content at the end of the period Teachers also give } \\
\text { students the opportunity to participate in the summary of the content. }\end{array}$ & 3.610 & .887 & good \\
\hline 15. & The given learning assessments are appropriate. Emphasis on real-world & 3.680 & .776 & good \\
\hline 16. & assessment. & 3.520 & .778 & good \\
\hline 17. & $\begin{array}{l}\text { Learning activities provide students with hands-on experiences together. } \\
\text { The activities that teachers use are appropriate. }\end{array}$ & 3.680 & .686 & good \\
\hline 18. & $\begin{array}{l}\text { Students enjoy participating in classroom activities that students use in } \\
\text { teaching and learning activities. }\end{array}$ & 4.030 & .756 & good \\
\hline 19. & $\begin{array}{l}\text { Learning activities, students learn the content along with practice leading } \\
\text { to greater understanding. }\end{array}$ & 3.860 & .788 & good \\
\hline 20. & $\begin{array}{l}\text { Learning activities make students dare to think, dare to speak, and } \\
\text { express themselves more. } \\
\text { Students can apply the knowledge gained from participating in } \\
\text { classroom activities to everyday life. }\end{array}$ & 3.980 & .766 & good \\
\hline & Summarize & 3.948 & .795 & good \\
\hline
\end{tabular}

\section{Discussion and Conclusions}

1) Physical education teaching style after the Covid-19 situation based on the concept of active learning with digital technology media of students in Physical Education and Health Education Faculty of Education National Sports University Chon Buri Campus consisted of the six-step learning management process known as PODARE Model as shown in Figure 3 consists of. 


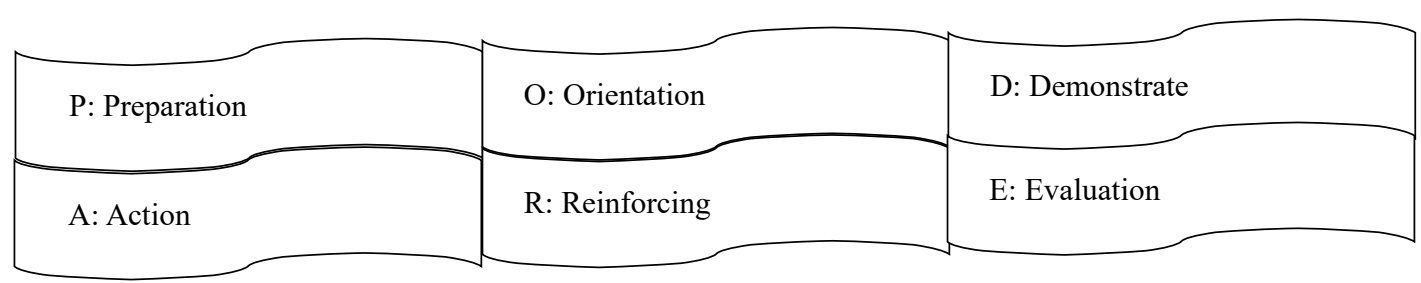

Figure 3. The Six-step Learning Management Process

It follows the Behavior Principle which states that feelings, cognitive and behavior interact with each other Reciprocal Determinism Kalish. (1981). A good attitude towards what approach will enable them to perform desirable behaviors and concept of Schwart (1975). The relationship of learning behaviors in all three areas was Buddhist phisai aspect. Mental Range and Range Skills (Knowledge-Attitudes-Practices: KAP Model) that knowledge affects practice both directly and indirectly. There is a mediator attitude that leads to compliance.

2) Comparison of proactive learning behavior with digital technology media of students in the experimental group that students managed to learn by using a model of proactive learning management with digital technology media. The active learning behaviors in combination with digital technology of students in the experimental group and the control group were different. It was statistically significant at the .05 level by active learning behavior with digital technology media of students in the experimental group that students managed to learn by using a model of active learning management with digital technology media. The mean was higher than the control group that the students managed to learn using the normal model. This is in line with the research by Kimsungnoen (2014) who studied the effect of participatory teaching and learning in community health nursing on academic achievement of nursing students at Rangsit University and found that students Nurses were satisfied with teaching and learning through participative learning style. This is consistent with Christopher (2021) showed that digital media-related classroom projects help students raise intercultural awareness of the cultural norms depicted in the digital images/illustrations they search for online. The study concludes that designing classroom intercultural projects using digital images/illustrations may promote student intercultural communicative competence in Japan. Herrmann, Lindvig \& Aagaard (2021). Found that digital technology constitutes a substantial presence in higher education. Students expressed mostly positive attitudes towards resulting class engagement and mostly negative attitudes towards taking, sharing, and searching their notes. Jones, Baek \& Wyant (2017) Student Clientele, Self as Teacher, and Others as Systems of Support as contributing agents in preservice teachers experiences integrating technology. Enhance our understanding of factors that facilitate and hinder early career Physical Education teachers use of technology in teaching and learning settings.

3) Assessment of advanced thinking of students in the experimental group that students managed to learn by using a active learning management model with digital technology media and the control group that students managed to learn by using the tradition model with a total of 600 students. The experimental group received learning management according to the active learning management model with digital technology media. $43.83 \%$ had a good advanced thinking score followed by higher thinking scores at the Very good, representing 20 percent and having a good advanced thinking score accounted for $16.17 \%$, respectively, which is consistent with concept of Brooks (1992). which has proposed 5 guidelines for developing self-esteem which are (1) developing responsibility and giving Help for the public (2) Allows them to think about alternatives and make decisions to solve problems (3) Provide support encouraging and providing positive feedback; (4) enhancing self-discipline by creating guidelines and Consider the consequences. (5) Help students feel accepting of failures or mistakes. Marttinen, Landi, Fredric \& Silverman (2020) Teachers integrated wearable digital technologies in ways they thought would augment their Physical Education programs, not replace them. Teachers were willing to integrate wearable digital technologies if they augmented (and did not replace) their preferred purpose of PE. Given this, ideologies of teachers influenced the role that technologies played in teaching and learning in PE.

4) After participating in the development of a model of proactive learning management with digital technology media and applying the model to an experiment, 15 students in the experimental group suggested that the model of proactive learning management with digital technology media allowed them to have a clearer understanding of proactive learning management with digital technology media. When the students changed the way they organized learning, the activities in the classroom changed and the students changed their learning behavior. This encouraged students to have more participation behavior in class. According to concept of Bloom (1971), the six stages are knowledge and memory remembering, understanding, applying, analyzing, evaluating, and creating. This is in line with the concept of Mayer (1993) who divided activities of active learning management into 2 dimensions, namely cognitive activities and 
behavioral activity. The active learning management aims to create a process in cognitive activities and requires behavioral activities. Therefore, teachers needed to manage learning in both dimensions. The result of learning results in a good high thinking score. Elfeky (2019) Findings showed that there was a statistically significant difference between the modified gain ratio of participants' degrees in the first experimental group that was taught through the Personal Learning Environments and second experimental group that received learning via Learning Management System in accordance to participants' higher-order thinking and satisfaction in favor of the first experimental group.

\section{Recommendations}

1) Teachers and students teaching physical education courses can use the teaching model as a guideline for teaching physical education according to the concept of active learning with digital technology of students.

2. In this research, faculty members and administrators can apply the model of teaching physical education in the situation of COVID-19 based on the concept of active learning with digital technology media by the Faculty of Education, the producer of physical education teachers to develop the ability to manage teaching and learning in online teaching as well.

3. Using the teaching model as a guideline for teaching physical education based on the concept of Active Learning with digital technology of students. There are many advantages but also disadvantages. Teachers should therefore be careful and solve problems of students who use such teaching as well.

\section{Suggestion for Further Research}

There should be education and development of physical education teaching styles based on various concepts that develop students from the current situation in the world. To develop competency in learning management that students cannot learn at school and to enable students to develop knowledge and abilities according to the objectives set.

\section{Acknowledgments}

The research team would like to thank the Thailand National Sports University Chon Buri Campus Funding for research on the development of physical education teaching model in the Covid-19 situation based on the concept of active learning in conjunction with digital technology media of students in Physical Education and Health Education Faculty of Education Thailand National Sports University Chon Buri Campus.

\section{References}

Alyami, H. Y. (2020). Integration of Open Educational Resources in Higher and General Education Institutions: from the Perspectives of Specialized and Concerned Bodies in E-Learning. World Journal of Education, 10(1), 30-41. https://doi.org/10.5430/wje.v10n1p30

Bloom, B. S. (1971). Handbook of Formative and Summative Evaluation of Student Learning. New York: Mc Graw-Hill Book Company.

Brooks, R. B. (1992). Self-Esteem during the School Years. Pediatric Clinics of North America, 39(3), 537-551. https://doi.org/10.1016/S0031-3955(16)38343-2

Christopher, A. (2021). Using Digital Media for Promoting Student Intercultural Awareness in Japan. Journal of Educational Multimedia and Hypermedia, 30(2), 117-138.

Chularat, P. (2018). Learning Management for Students in the Thailand 4.0 Era (Learning Management for Students in the Thailand 4.0 Era). Viridian E-Journal, Silpakorn Universit, 11(2), 2363-2380.

Elfeky, A. I. M. (2019). The effect of personal learning environments on participants' higher order thinking skills and satisfaction. Innovations in Education and Teaching International, 56(4), 505-516. https://doi.org/10.1080/14703297.2018.1534601

Feng, Z. (2013). Using Teacher Questions to Enhance EFL Students' Critical Thinking Ability. Journal of Curriculum and Teaching, 2(2), 147-153. https://doi.org/10.5430/jct.v2n2p147

Ghafar, A. (2020). Convergence between 21st Century Skills and Entrepreneurship Education in Higher Education Institutes. International Journal of Higher Education, 9(1), 218-229. https://doi.org/10.5430/ijhe.v9n1p218 
Ghazala, A. F., \& Elshall, S. E. (2021). Application of National Education Technology Standards as Perceived by Nursing Students and Its Relation to Their Problem Solving Skill during COVID-19 Disaster. International Journal of Higher Education, 10(2), 172-187. https://doi.org/10.5430/ijhe.v10n2p172

Herrmann, K. J., Lindvig, K., \& Aagaard, J. (2021). Curating the use of digital media in higher education: a case Study. Journal of Further and Higher Education, 45(3), 389-400. https://doi.org/10.1080/0309877X.2020.1770205

Jones, E. M., Baek, J., \& Wyant, J. D. (2017). Exploring Pre-Service Physical Education Teacher Technology Use during Student Teaching. Journal of Teaching in Physical Education, 36(2), 173-184. https://doi.org/10.1123/jtpe.2015-0176

Kalish, H. I. (1981). From behavior science to behavior modification. New York: McGraw-Hill.

Kimsungnoen, N. (2014). The effect of participatory teaching and learning in community health nursing on academic achievement of students. Faculty of Nursing Rangsit University. Teaching and Learning Development Journal Rangsit University.

Koludrović, M., \& Ercegovac, I. R. (2017). Does Higher Education Curriculum Contribute to Prospective Teachers' Attitudes, Self-Efficacy and Motivation? World Journal of Education, 7(1), 93-104. https://doi.org/10.5430/wje.v7n1p93

Marttinen, R., Landi, D., Fredrick, R. N., \& Silverman, S. (2020). Wearable Digital Technology in PE: Advantages, Barriers, and Teachers' Ideologies. Journal of Teaching in Physical Education, 39(2), 227-235. https://doi.org/10.1123/jtpe.2018-0240

Ma-un, R. (2016). Efficient management of teaching and learning in higher education. Southern Technology Journal, 9(2), 169-176.

Mayers, C., \& Lohn, T. B. (1993). Promoting Active Learning: Strategies for the Collage Classroom. San Francisco: Jossey-Bass.

Ministry of Education. (2010). National Education Act Amendment (No. 2) B.E. 2545 and (No. 3) B.E. 2010. Retrieved from http://www.moe.go.th

Panich, C. (2013). Teacher for students. Create a classroom back the way. Bangkok: SR Printing Mass Products Ltd.

Romualdas, M., \& Tomas, S. (2020). Dynamics of the Sociability of Future PE Teachers in the First Decades of the 21st Century. European Journal of Contemporary Education, 9(1), 67-75. https://doi.org/10.13187/ejced.2020.1.67

Schwartz, N. E. (1975). Nutrition Knowledge, attitude, and practice of high school Graduates. Journal of the American Dietetir Association, 66, 28-31.

Sukdee, T., \& Chankuna, D. (2021). Factors influencing adjustment in physical education and sports learning after the COVID-19 pandemic among students in the faculty of education at Thailand national sports university. World Journal of Education, 11(2), 24-35. https://doi.org/10.5430/wje.v11n2p24

Ying, J. (2020). Embedding and Facilitating Intercultural Competence Development in Internationalization of the Curriculum of Higher Education. Journal of Curriculum and Teaching, 9(3), 13-19. https://doi.org/10.5430/jct.v9n3p13

\section{Copyrights}

Copyright for this article is retained by the author(s), with first publication rights granted to the journal.

This is an open-access article distributed under the terms and conditions of the Creative Commons Attribution license (http://creativecommons.org/licenses/by/4.0/). 